\title{
Correction to: ASO Visual Abstract: Contribution of Genomics to the Surgical Management and Study of Oral Cancer
}

\author{
Zuzana Saidak, $\mathrm{PhD}^{1,2}$, Claire Lailler, PharmD ${ }^{1,2}$, Sylvie Testelin, MD, PhD ${ }^{1,3}$, Bruno Chauffert, MD, $\mathbf{P h D}^{1,4}$, \\ Florian Clatot, $\mathrm{MD}, \mathrm{PhD}^{5,6}$, and Antoine Galmiche, $\mathrm{MD}, \mathrm{PhD}^{1,2}$ \\ ${ }^{1}$ UR7516 «CHIMERE », Université de Picardie Jules Verne, Amiens, France; ${ }^{2}$ Centre de Biologie Humaine, CHU \\ Amiens, Amiens, France; ${ }^{3}$ Department of Maxillofacial Surgery, CHU Amiens, Amiens, France; ${ }^{4}$ Department \\ of Oncology, CHU Amiens, Amiens, France; ${ }^{5}$ Centre Henri Becquerel, Rouen, France; ${ }^{6}$ INSERM U1245/team IRON, \\ Rouen, France
}

\section{CORRECTION TO:}

ANN SURG ONCOL

HTTPS://DOI.ORG/10.1245/S10434-021-10004-2

The article "ASO Visual Abstract: Contribution of Genomics to the Surgical Management and Study of Oral Cancer", written by Saidak et al., was originally published online on the publisher's internet portal on May 6, 2021, with Open Access under a Creative Commons Attribution
(CC BY) license 4.0. With the authors' decision to cancel Open Access the copyright of the article changed on June 9, 2021 to $($ S Society of Surgical Oncology 2021 with all rights reserved.

The original article has been updated.

Publisher's Note Springer Nature remains neutral with regard to jurisdictional claims in published maps and institutional affiliations.

The original article can be found online at https://doi.org/10.1245/ s10434-021-10004-2.

(C) Society of Surgical Oncology 2021

Published Online: 13 July 2021

Z. Saidak, $\mathrm{PhD}$

e-mail: Saidak.Zuzana@chu-amiens.fr 